\title{
Article \\ Hemp Seeds of the Polish 'Bialobrzeskie' and 'Henola' Varieties (Cannabis sativa L. var. sativa) as Prospective Plant Sources for Food Production
}

\author{
Mirosława Teleszko ${ }^{1, *}$, Adam Zając ${ }^{2}(\mathbb{D})$ and Tomasz Rusak ${ }^{3}$ \\ 1 Department of Food Technology and Nutrition, Wroclaw University of Economics and Business, \\ Komandorska 118/120 Street, 53-345 Wroclaw, Poland \\ 2 Department of Bioorganic Chemistry, Wroclaw University of Economics and Business, \\ Komandorska 118/120 Street, 53-345 Wroclaw, Poland; adam.zajac@ue.wroc.pl \\ 3 BIOTRECO Sp. z o.o., Łakowa 2C Street, 55-040 Bielany Wrocławskie, Poland; tomasz.rusak@biotreco.pl \\ * Correspondence: miroslawa.teleszko@ue.wroc.pl
}

Citation: Teleszko, M.; Zając, A.; Rusak, T. Hemp Seeds of the Polish 'Bialobrzeskie' and 'Henola' Varieties (Cannabis sativa L. var. sativa) as Prospective Plant Sources for Food Production. Molecules 2022, 27, 1448 https://doi.org/10.3390/ molecules 27041448

Academic Editor: Bruno Botta

Received: 29 December 2021

Accepted: 17 February 2022

Published: 21 February 2022

Publisher's Note: MDPI stays neutral with regard to jurisdictional claims in published maps and institutional affiliations.

Copyright: (C) 2022 by the authors. Licensee MDPI, Basel, Switzerland. This article is an open access article distributed under the terms and conditions of the Creative Commons Attribution (CC BY) license (https:// creativecommons.org/licenses/by/ $4.0 /)$.

\begin{abstract}
This publication characterizes the nutritional value of the Polish hemp seeds of the 'Bialobrzeskie' and 'Henola' varieties, including the profile/content of fatty acids and amino acids. Hemp seeds were found to be rich in protein, fat, and dietary fiber. Polyunsaturated fatty acids (PUFA) dominated the unsaturated fatty acids (UFA) profile. Their average share within the total fatty acids (FA) was as high as $75 \%$. Linoleic acid belonging to this group accounted for $55 \%$ of the total FA. Lipid profile indices $(\Sigma n-6 / \Sigma n-3, \Sigma$ PUFA $/ \Sigma$ SFA, the thrombogenicity index, the atherogenicity index and the hypocholesterolemic/hypercholesterolemic ratio) proved the high nutritional value of hemp oil. Considering the tyrosine + phenylalanine and histidine contents, hemp protein exhibited a great degree of similarity to egg protein, which is known and valued for its high biological value.
\end{abstract}

Keywords: hemp seeds; nutrition value; fatty acids; amino acids; plant-based food

\section{Introduction}

According to the European Industrial Hemp Association (EIHA) report of 2018, industrial hemp (Cannabis sativa) production on the Old Continent covers an area of 50,081 ha and the yearly average has increased by over $600 \%$ compared to the production recorded in 1993 [1]. The usable parts of hemp include leaves and flowers that are used, for example, for the manufacture of food supplements (58\%), essential oils (20\%) and tea (6\%), as well as for medical applications (1\%) and other uses, e.g., in the cosmetic industry (15\%). The primary seed processing lines include the production of hemp flour, animal feed, fiber preparations, husked seeds, and food, mainly oil.

According to analysts from New frontier Data [2], Poland has significant potential to become one of the key producers of hemp in Europe. There are many arguments to support this. The acreage of Cannabis sativa in Poland recorded an 80\% increase in 2018-2020 and now totals around 3000 ha. The sales value of industrial hemp farming amounted to USD 9.6 million, providing a raw material base for the textile, food, cosmetic and construction industries. Essential market players, such as Canopy Growth, Aurora and Australian GC Pharma, started recognizing the promising opportunities in the Polish hemp industry [2]. At present, the Polish National List of Agricultural Plant Varieties includes 11 varieties of industrial hemp, i.e., the 'Beniko', 'Bialobrzeskie', 'Glyana', 'Henola', 'Mietko', 'Rajan', 'Sofia', 'Tigra', 'Wielkopolskie' and 'Wojko' monoecious varieties, as well as the 'Matrix' dioecious variety. They all exhibit tetrahydrocannabinol (THC) content in the dry matter of the inflorescence mass not exceeding $0.2 \%$ [3].

In recent years, the global economic expansion of hemp has taken several directions. The considerable interest in the medicinal applications of this plant is based on the centuriesold experience of using Cannabis sativa in the folk medicine of China, Assyria, Egypt, and 
ancient Greece and Rome [4,5]. Already 5000 years ago, the first Chinese pharmacopeia by the emperor Chen Nung mentioned prescribing cannabis as a drug for fatigue, malaria and rheumatism [6]. Hemp's phytocannabinoids, including $\Delta$-9-tetrahydrocannabinol $(\Delta-9$ THC) and cannabidiol (CBD), and their therapeutic properties, are the subjects of research in many scientific centers worldwide. Their thematic scope is diverse and includes, among others, the assessment of the potential use of these compounds in treating neurological diseases (including epilepsy) [7,8], mental disorders (including anxiety, clinical depression and sleep disorders) [9], pain [10,11], cancer [12], rheumatoid arthritis [13] or Crohn's disease [14].

Food production is also an essential and highly prospective direction for the use of hemp, particularly with the dynamically developing vegan food industry in mind. The desire to limit the production and consumption of meat worldwide is undeniable. According to the European Commission's forecasts [15], meat consumption in the Community will decrease from $68.7 \mathrm{~kg}$ per capita in 2020 to $67.6 \mathrm{~kg}$ per capita in 2030. This decrease will mainly result from a change in consumer preferences and a reduction in the consumption of red meat. As Aschemann-Witzel et al. [16] noted, the growing global demand for protein, its insufficient consumption in certain population groups, as well as the numerous advantages of plant protein (health aspects, sustainable development, etc.) have provided an impulse for the development of modern protein products of plant origin and contributed to the growing popularity of plant products and diets. In this context, hemp seeds appear to provide a lot of application opportunities. This raw material is rich in easily digestible protein (20-25\%) with a favorable amino-acid profile. It also contains $25-35 \%$ lipids with a unique and perfectly balanced fatty acid composition. The share of carbohydrates is high at $20-30 \%$, with a significant proportion of this fraction being dietary fiber (primarily insoluble) [17]. Hemp seeds are also a valuable source of many mineral components (e.g., P, $\mathrm{K}, \mathrm{Mg}, \mathrm{Ca}, \mathrm{Na}$ and $\mathrm{Fe}$ ) [18].

Given the considerations presented above, the purpose of this work was to determine the nutritional value of hemp seeds of two Polish varieties, 'Henola' and 'Bialobrzeskie', and to determine their possible use for the production of valuable plant products.

\section{Results and Discussion}

\subsection{Nutritional and Energy Value of Hemp Seeds}

Seeds of the tested hemp varieties exhibited similar nutritional quality parameters (Table $1 ; p<0.05$ ). They contained $32.52 \%$ fat (mean value), $23.47 \%$ protein, $2.05 \%$ total sugars and $4.66 \%$ total ash. The digestible carbohydrates content of the 'Henola' variety was greater than estimated for the 'Bialobrzeskie' variety $(4.48 \%)$. However, in 'Bialobrzeskie' seeds, a higher content of dietary fiber was noted $(28.88 \%)$. Hemp seeds thus have a valuable chemical composition. The analysis of their main features already shows a broad spectrum of potential raw material applications in food production.

Table 1. Nutritional and energy value of hemp seeds.

\begin{tabular}{lccc}
\hline \multicolumn{1}{c}{ Parameter } & & \multicolumn{2}{c}{ HEMP } \\
\cline { 3 - 4 } & & 'Bialobrzeskie' & 'Henola' \\
\hline Energy value & $\mathrm{kJ} / 100 \mathrm{~g}$ & $1860 \pm 18.83 \mathrm{a}$ & $1905 \pm 11.31 \mathrm{a}$ \\
Energy value & $\mathrm{kcal} / 100 \mathrm{~g}$ & $451 \pm 4.46 \mathrm{a}$ & $461 \pm 2.74 \mathrm{a}$ \\
Dry matter & $\%$ & $91.38 \pm 2.25 \mathrm{a}$ & $92.44 \pm 0.64 \mathrm{a}$ \\
Protein * & $\%$ & $23.54 \pm 0.59 \mathrm{a}$ & $23.39 \pm 0.38 \mathrm{a}$ \\
Total sugars * & $\%$ & $2.01 \pm 0.11 \mathrm{a}$ & $2.09 \pm 0.01 \mathrm{a}$ \\
Digestible carbohydrates * & $\%$ & $2.02 \pm 0.24 \mathrm{a}$ & $4.48 \pm 0.25 \mathrm{~b}$ \\
Dietary fiber * & $\%$ & $28.88 \pm 0.18 \mathrm{a}$ & $27.42 \pm 0.34 \mathrm{~b}$ \\
Fat (total) * & $\%$ & $32.28 \pm 0.41 \mathrm{a}$ & $32.75 \pm 1.70 \mathrm{a}$ \\
Saturated fatty acids (SFA) * & $\mathrm{g} / 100 \mathrm{~g}$ & $3.48 \pm 0.40 \mathrm{a}$ & $3.98 \pm 0.25 \mathrm{a}$ \\
Ash (total) * & $\%$ & $4.66 \pm 0.47 \mathrm{a}$ & $4.40 \pm 0.16 \mathrm{a}$ \\
\hline a, b-mean values within a row with different letters are significantly different at $p<0.05 ;{ }^{*}$ according to the dry \\
matter (DM) of seeds.
\end{tabular}


Our research confirmed that fat is a crucial component of hemp seed. As read in the literature, its share in seeds is subject to several factors, including plant genotype [19], climate and agronomic conditions [20]. Vonapartis et al. [21] found that the fat content in seeds of 10 hemp varieties grown in Canada ranged from 269 ('Delores') to $306 \mathrm{~g} / \mathrm{kg}$ of dry matter (DM; 'Finola'). Lan et al. found higher oil levels in the analyzed hemp seeds [22]. In the ten varieties from North Dakota crops, USA, tested by Lan et al., fat accounted for between 32.75 (' $\mathrm{X}-59^{\prime}$ ) and $35.88 \%$ of dry matter ('CFX-1'). Thus, similar results were obtained in our research on Polish 'Henola' and 'Bialobrzeskie' varieties (Table 1). From the study published by Mihoc et al. [23], it follows that varieties grown in Romania were much less rich in fat. Depending on the harvesting season (2010 and 2011), the oil content of the seeds ranged from 20.82 ('Diana') to $29.27 \%$ ('Armanca'). However, these authors pointed out that the monthly average temperatures in the flowering period combined with low rainfall levels could contribute to the incomplete ripening of the seeds and decreases in their oil content. In turn, from the experiment of Alonso-Esteban et al. [24], it was found that of the eight hemp varieties examined, 'Fedora 17' was the richest in oil $(32.24 \%)$. In the 'Bialobrzeskie' variety, its content did not exceed 29\%. These observations thus confirm that, in addition to variety, the geographical crop location and the resulting soil and climate conditions also significantly impact the fat content in Cannabis sativa seeds.

From the nutritional quality and potential health advantages point of view, hemp oil is considered to have a beneficial effect on human metabolism, which is linked not only to the high content of polyunsaturated fatty acids (PUFA) from the $n-3$ and $n-6$ families, but also to their proportions [25]. We discuss this topic in detail in the section entitled "Fatty Acids Profile and Lipid Indices".

It follows from our research that hemp seeds of the 'Henola' and 'Bialobrzeskie' varieties are a valuable source of protein, with their contents exceeding $23 \%$ in both varieties. These values are similar to those determined for other industrial hemp varieties by House et al. [26], Vonapartis et al. [21] and Siano et al. [27]. As Wang and Xong [28] noted, due to their high nutritional value, hemp protein is increasingly gaining interest in research centers worldwide, reflected in a dynamically growing number of publications on it. Hemp has good application potential for producing the so-called protein flour, isolates and protein concentrates [29], and drinks such as plant "milk" [30].

Cannabis seed mainly consists of storage proteins, including albumins (25-37\%) and edistin/globulin (67-75\%). They do not contain protease inhibitors, which results in improved digestive properties of the protein. The content of essential amino acids in hemp seed proteins is higher than in those of soya and is sufficient for people of ten years and older. The amino acid profile of the proteins found in seeds of the 'Henola' and 'Bialobrzeskie' varieties has been described in detail in the "Amino Acids Profile and Content" section.

High fiber content also needs to be mentioned when assessing the nutritional quality of hemp seeds. In the studied material, the fiber content was 28.88 and $27.42 \%$ (Table $1 ; p<0.05$ ). According to other authors, these values range from $27.6 \%$ to as much as $33.8 \%$ [18,31]. Among other things, fiber-rich hemp can be used to create new bakery formulas. In their research, Korus et al. [32] successfully used hemp flour as an additive to starch to bake gluten-free bread, which had a beneficial effect on the product's taste, color, fiber and protein content. Teterycz et al. [33] used hemp flour and hemp cake as an additive to semolina-based pasta, which allowed the pasta to become enriched with fiber (including insoluble dietary fiber (IDF) and neutral detergent fiber (NDF) fractions) and protein.

\subsection{Fatty Acid Profile and Lipid Indices}

Hemp oil is considered to be one of the most valuable edible oils because of the unique profile of its fatty acids (FA; Table 2) and their mutual relationships were analyzed concerning the lipid quality indicators, including the PUFA/SFA acid ratio, $n-6 / n-3$ acid ratio, the atherogenicity index (AI), the thrombogenicity index (TI) and the hypocholesterolemic/hypercholesterolemic ratio $(\mathrm{h} / \mathrm{H})$. 
Table 2. Fatty acid (FA) profile/content in hemp seeds.

\begin{tabular}{|c|c|c|c|c|c|}
\hline \multirow{2}{*}{ Fatty Acid } & \multirow{2}{*}{ Chemical Structure } & 'Bialobrzeskie' & 'Henola' & 'Bialobrzeskie' & 'Henola' \\
\hline & & \multicolumn{2}{|c|}{$(\%)$ in total FA } & \multicolumn{2}{|c|}{ (g/100 g DM of Seeds) } \\
\hline palmitic & $\mathrm{C} 16: 0$ & $6.75 \pm 0.71 \mathrm{a}$ & $7.76 \pm 0.89 \mathrm{a}$ & 2.18 & 2.54 \\
\hline palmitoleic & $\mathrm{C} 16: 1 n-7$ & $0.16 \pm 0.05 a$ & $0.16 \pm 0.02 \mathrm{a}$ & 0.05 & 0.05 \\
\hline margaric & $\mathrm{C} 17: 0$ & $0.07 \pm 0.00 \mathrm{a}$ & $0.06 \pm 0.00 \mathrm{a}$ & 0.02 & 0.02 \\
\hline stearic & C18:0 & $2.65 \pm 0.08 \mathrm{a}$ & $2.84 \pm 0.11 \mathrm{a}$ & 0.86 & 0.93 \\
\hline oleic & $\mathrm{C} 18: 1 n-9$ & $12.28 \pm 1.75 \mathrm{a}$ & $11.95 \pm 1.37 \mathrm{a}$ & 3.96 & 3.91 \\
\hline cis-vaccenic & $\mathrm{C} 18: 1 n-7(11 \mathrm{cis})$ & $0.96 \pm 0.07 \mathrm{a}$ & $0.96 \pm 0.09 \mathrm{a}$ & 0.31 & 0.31 \\
\hline linoleic & $\mathrm{C} 18: 2 n-6$ & $56.46 \pm 2.40 \mathrm{a}$ & $53.35 \pm 3.01 \mathrm{a}$ & 18.22 & 17.48 \\
\hline$\gamma$-linolenic & $\mathrm{C} 18: 3 n-6$ & $3.33 \pm 0.41 \mathrm{a}$ & $1.56 \pm 0.13 b$ & 1.07 & 0.51 \\
\hline$\alpha$-linolenic & $\mathrm{C} 18: 3 n-3$ & $14.60 \pm 1.85 \mathrm{a}$ & $19.15 \pm 2.06 \mathrm{a}$ & 4.71 & 6.27 \\
\hline stearidonic & $\mathrm{C} 18: 4 n-3$ & $0.87 \pm 0.11 \mathrm{a}$ & $0.00 \pm 0.00 \mathrm{~b}$ & 0.28 & 0.00 \\
\hline arachidic & C20:0 & $0.77 \pm 0.09 \mathrm{a}$ & $0.86 \pm 0.11 \mathrm{a}$ & 0.25 & 0.28 \\
\hline cis-11-eicosenoic & C20:1 & $0.34 \pm 0.06 \mathrm{a}$ & $0.43 \pm 0.04 \mathrm{a}$ & 0.11 & 0.14 \\
\hline eicosadienoic & C20:2 & $0.06 \pm 0.01 \mathrm{a}$ & $0.06 \pm 0.00 \mathrm{a}$ & 0.02 & 0.02 \\
\hline behenic & $\mathrm{C} 22: 0$ & $0.31 \pm 0.05 \mathrm{a}$ & $0.34 \pm 0.06 \mathrm{a}$ & 0.10 & 0.11 \\
\hline erucic & $\mathrm{C} 22: 1 n-9$ & $0.00 \pm 0.00 \mathrm{~b}$ & $0.07 \pm 0.00 \mathrm{a}$ & 0.00 & 0.02 \\
\hline lignoceric & $\mathrm{C} 24: 0$ & $0.14 \pm 0.00 \mathrm{a}$ & $0.17 \pm 0.00 \mathrm{~b}$ & 0.05 & 0.06 \\
\hline nervonic & $\mathrm{C} 24: 1 n-9$ & $0.00 \pm 0.00 \mathrm{~b}$ & $0.07 \pm 0.01 \mathrm{a}$ & 0.00 & 0.02 \\
\hline
\end{tabular}

$\mathrm{a}, \mathrm{b}-$ mean values within a row with different letters are significantly different at $p<0.05$.

Our research confirmed that hemp lipids are characterized by a high proportion of unsaturated acids (UFA). In the oil fraction extracted from seeds of the 'Henola' and 'Bialobrzeskie' varieties, the share of these acids accounted for, on average, $88 \%$ of the total FA. Polyunsaturated fatty acids (PUFA) dominated the UFA profile. Their average percentage in total FA was as high as $75 \%$, corresponding to a concentration of around $24 \mathrm{~g}$ PUFA /100 g (Figure 1). Linoleic acid (C18:2 $n-6 \mathrm{c}$; LA) belonging to this group accounted for $55 \%$ of the total FA content (mean value). The presence of $\alpha$-linolenic acid (C18:3 $n-3$; ALA) was also well emphasized among the PUFA acids, and was particularly evident in the lipid profile of the 'Henola' variety (ALA share $>19 \%$ ). When comparing the hemp varieties tested in terms of $\gamma$-linolenic acid (C18:3n-6; GLA), we found it to be twice as high in the lipid extract from the 'Bialobrzeskie' seeds (more than 3\%). Interestingly, the FA identified in this variety also included four-unsaturated stearidonic acid (SDA), belonging to the $n-3$ family. This 18-carbon PUFA is a direct product of the conversion of ALA catalyzed by $\Delta-6$ desaturase. SDA is a component of many fish oils, but it is also found in plant seeds, especially the species of the Boraginaceae family. This compound is found in significant amounts in Ahiflower oil [34].

Oleic acid was the major MUFA acid in hemp seeds (mean value: $12 \%$ ). The share of remaining compounds in MUFA, including cis-vaccenic, cis-11-eicosenoic and palmitoleic acids, did not exceed $1 \%$ of the total FA in any of the cases. In addition, trace amounts of erucic and nervonic acids were found in 'Henola' seeds (Table 2).

Saturated acids accounted for an average of $11 \%$ of the total FA, with only long-chain acids found in hemp seeds. C16:0 (palmitic acid) was their leading representative with a concentration averaging $2 \mathrm{~g} / 100 \mathrm{~g}$ of the sample.

The lipid profile indices proved the nutritional value of hemp oil. Table 3 presents their values. The PUFA/SFA ratio and the $n-6 / n-3$ ratio are used mainly to assess the effect of diet on the cardiovascular system. The PUFA ratio is based on the general assumption that PUFAs can reduce low-density lipoprotein (LDL) and serum cholesterol levels. In contrast, SFA has a hypercholesterolemic effect [35]. PUFA/SFA ratios exceeding 0.45 coupled with $n-6 / n-3$ ratios below 5 are considered to be beneficial in the diet because of their high potential for preventing cardiovascular diseases. The PUFA/SFA ratio in the tested samples ranged from 6 to 7 , whereas that of $n-6 / n-3$ acids was approximately 3-4. Tringaniello et al. [36] found similar values of these ratios in hemp oils, indicating that a high proportion of polyunsaturated to saturated acids is considered 
beneficial for lowering serum cholesterol levels, reducing the risk of atherosclerosis and preventing heart disease. At the same time, the PUFA/SFA values determined in hemp oil in our study were much higher than those determined by Kim et al. [37] in olive oil (0.56), soybean oil (4.16), sesame oil (3.21), corn oil (4.25) or rapeseed oil (4.63).

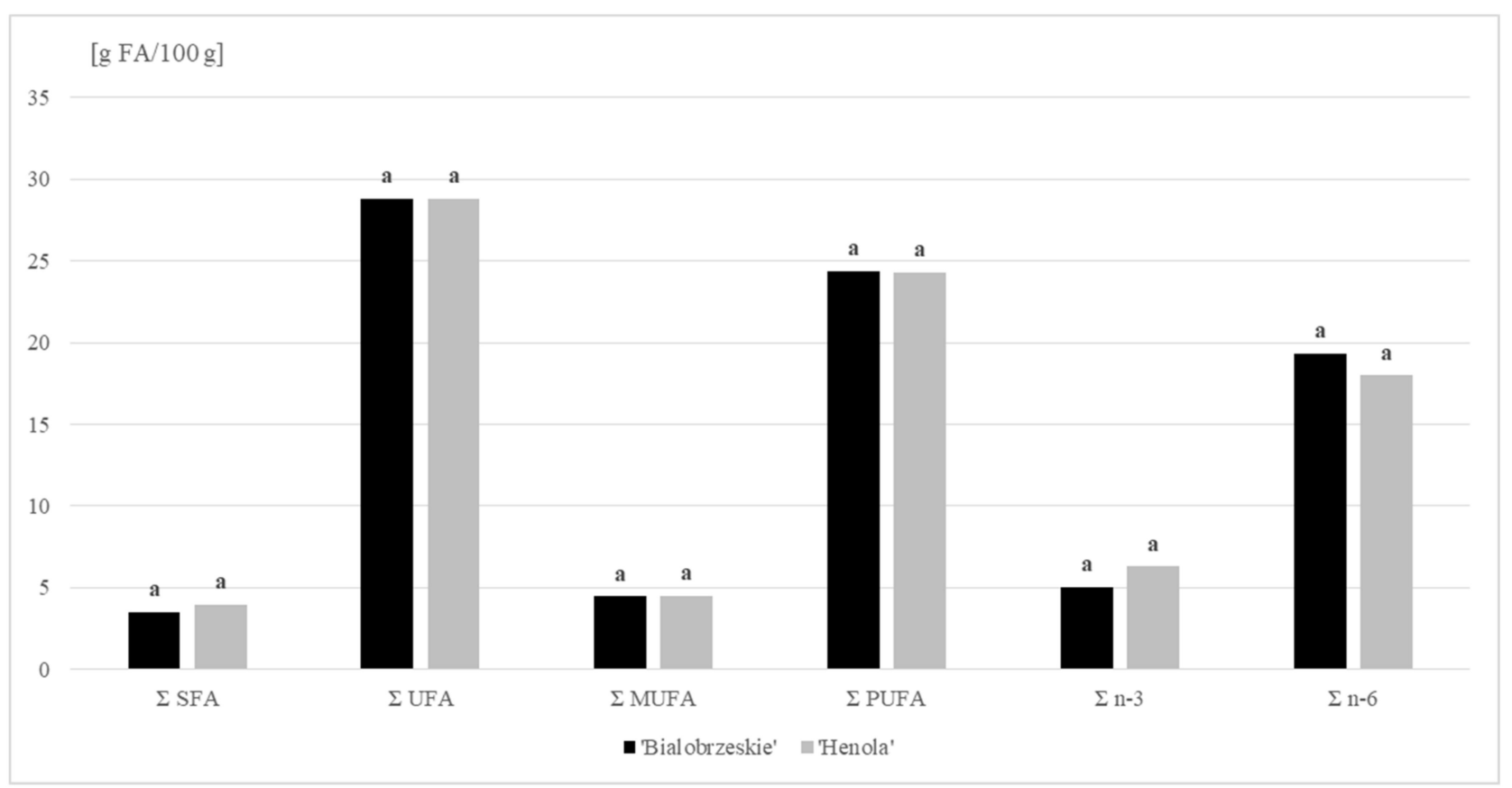

Figure 1. Fatty acids (FA) content (g/100 g DM) in 'Bialobrzeskie' and 'Henola' seeds.

Table 3. Lipid health indicators of hemp seeds.

\begin{tabular}{ccc}
\hline Quality Parameters & 'Bialobrzeskie' & 'Henola' \\
\hline$\Sigma n-6 / \sum n-3$ & $3.86 \pm 0.33 \mathrm{a}$ & $2.87 \pm 0.61 \mathrm{a}$ \\
$\Sigma$ PUFA $/ \Sigma$ SFA & $7.06 \pm 1.03 \mathrm{a}$ & $6.17 \pm 0.73 \mathrm{a}$ \\
AI & $0.08 \pm 0.01 \mathrm{a}$ & $0.09 \pm 0.01 \mathrm{a}$ \\
TI & $0.03 \pm 0.00 \mathrm{a}$ & $0.03 \pm 0.00 \mathrm{a}$ \\
$\mathrm{h} / \mathrm{H}$ & $12.98 \pm 3.00 \mathrm{a}$ & $11.21 \pm 1.82 \mathrm{a}$ \\
\hline
\end{tabular}

a-mean values within a row are not significantly different $(p<0.05)$.

The atherogenicity index (AI) is a lipid index that is often used in assessing the nutritional quality of plants, algae, fish, meat, dairy products and others. It indicates the relationship between the sum of pro-atherosclerotic SFA (C12:0, C14:0, C16:0) and anti-atherosclerotic UFA. The lowering of total cholesterol and LDL-C fraction in plasma is linked to the consumption of foods characterized by low AI. Our research showed that this ratio was below 0.1 in the fat extracted from hemp seeds (Table 3). GC analysis of the fatty acid profile showed that myristic and lauric acids were not detected in the tested samples. The share of palmitic acid was 6.75 ('Bialobrzeskie') and 7.76\% ('Henola'), respectively. The total percentage of UFA exceeded these values by more than 10 times, which ultimately resulted in a very low AI for hemp oil. The determined thrombogenicity index (TI) also proved the high nutritional quality of the tested samples. The IT values indicated a clot formation tendency in blood vessels, taking into account the relationship between prothrombogenic fatty acids (C12:0, C14:0 and C16:0) and the anticoagulant MUFA and PUFA $n-3$ and $n-6$ family [38]. In both 'Bialobrzeskie' and 'Henola' hemp seeds, the calculated TI was 0.03 . However, for the hypocholesterolemic/hypercholesterolemic $(\mathrm{h} / \mathrm{H})$ ratio, the values were 12.98 and 11.21 , respectively.

Similar AI values for hemp oil were obtained by other authors, including Razmaite et al. [29]. For the TI and $\mathrm{h} / \mathrm{H}$ ratios, Ying et al. [39] found higher values than those determined in 
our study. This was probably due to differences in the proportion of SFA, MUFA and PUFA $n-6$ and $n-3$ acids in hemp oils. From the analyses conducted by these researchers, it follows that the proportion of the FA mentioned above was 8.6, 10.7, 53.2 and 25.4\%, respectively [39]. Except for the proportion of PUFAs from the $n-3$ family, these values are lower than our study found.

\subsection{Amino Acids Profile and Content}

Table 4 summarizes the determined contents of 17 amino acids concerning the hemp seed weight (g/100 g DM of seeds) and hemp protein (g/100 g protein). In terms of the contents of essential amino acids, the raw materials studied were compared to a theoretical reference protein for people $>1$ year of age, according to the Institute of Medicine (IOM; Washington, DC, USA), in addition to egg protein (FAO/WHO) [40].

Table 4. Amino acid profile of hemp seeds.

\begin{tabular}{|c|c|c|c|c|c|c|}
\hline \multirow{2}{*}{ Amino Acids } & \multicolumn{2}{|c|}{ 'Bialobrzeskie' } & \multicolumn{2}{|c|}{ 'Henola' } & \multirow{2}{*}{$\begin{array}{l}\begin{array}{l}\text { Protein Pattern } \\
\text { IOM ** }\end{array} \\
\text { Content in Protei }\end{array}$} & \multirow{2}{*}{$\begin{array}{c}\begin{array}{c}\text { Egg } \\
\text { protein }\end{array} \\
(\mathrm{g} / 100 \mathrm{~g})\end{array}$} \\
\hline & $\begin{array}{l}\text { Content in Seeds } \\
(\mathrm{g} / 100 \mathrm{~g} \text { DM })\end{array}$ & $\begin{array}{c}\text { Content in } \\
\text { Protein }(\mathrm{g} / 100 \mathrm{~g})\end{array}$ & $\begin{array}{l}\text { Content in Seeds } \\
(\mathrm{g} / 100 \mathrm{~g} \text { DM })\end{array}$ & $\begin{array}{c}\text { Content in } \\
\text { Protein }(g / 100 g)\end{array}$ & & \\
\hline Lys * & $0.754 \pm 0.098 \mathrm{a}$ & 3.20 & $0.752 \pm 0.098 \mathrm{a}$ & 3.22 & 5.1 & 6.3 \\
\hline Met * & $0.497 \pm 0.065 \mathrm{a}$ & 2.11 & $0.463 \pm 0.060 \mathrm{a}$ & 1.98 & & \\
\hline Cys * & $0.330 \pm 0.060 \mathrm{a}$ & 1.40 & $0.320 \pm 0.060 \mathrm{a}$ & 1.37 & & \\
\hline Met + Cys * & 0.827 & 3.51 & 0.783 & 3.35 & 2.5 & 5.6 \\
\hline Asp & $2.160 \pm 0.280 \mathrm{a}$ & 9.18 & $2.020 \pm 0.260 \mathrm{a}$ & 8.64 & & \\
\hline Thr * & $0.718 \pm 0.093 \mathrm{a}$ & 3.05 & $0.648 \pm 0.084 \mathrm{a}$ & 2.77 & 2.7 & 4.7 \\
\hline Ser & $0.990 \pm 0.130 \mathrm{a}$ & 4.21 & $0.920 \pm 0.120 \mathrm{a}$ & 3.93 & & \\
\hline Glu & $3.590 \pm 0.390 \mathrm{a}$ & 15.25 & $3.410 \pm 0.380 \mathrm{a}$ & 14.58 & & \\
\hline Pro & $0.820 \pm 0.110 \mathrm{a}$ & 3.48 & $0.810 \pm 0.110 \mathrm{a}$ & 3.46 & & \\
\hline Gly & $0.930 \pm 0.120 \mathrm{a}$ & 3.95 & $0.880 \pm 0.110 \mathrm{a}$ & 3.76 & & \\
\hline Ala & $0.900 \pm 0.120 \mathrm{a}$ & 3.82 & $0.860 \pm 0.110 \mathrm{a}$ & 3.68 & & \\
\hline Val * & $0.970 \pm 0.130 \mathrm{a}$ & 4.12 & $0.980 \pm 0.130 \mathrm{a}$ & 4.19 & 3.2 & 6.9 \\
\hline $\mathrm{Ile}^{*}$ & $0.830 \pm 0.110 \mathrm{a}$ & 3.53 & $0.800 \pm 0.100 \mathrm{a}$ & 3.42 & 2.5 & 5.9 \\
\hline Leu * & $1.310 \pm 0.170 \mathrm{a}$ & 5.56 & $1.290 \pm 0.170 \mathrm{a}$ & 5.52 & 5.5 & 8.5 \\
\hline Tyr * & $0.571 \pm 0.074 \mathrm{a}$ & 2.43 & $0.523 \pm 0.068 \mathrm{a}$ & 2.24 & & \\
\hline Phe * & $0.890 \pm 0.120 \mathrm{a}$ & 3.78 & $0.930 \pm 0.120 \mathrm{a}$ & 3.98 & & \\
\hline Tyr + Phe * & 1.461 & 6.21 & 1.453 & 6.21 & 4.7 & 7 \\
\hline His * & $0.565 \pm 0.073 \mathrm{a}$ & 2.40 & $0.527 \pm 0.068 \mathrm{a}$ & 2.25 & 1.8 & 2.3 \\
\hline Arg & $2.480 \pm 0.320 \mathrm{a}$ & 10.54 & $2.260 \pm 0.290 \mathrm{a}$ & 9.66 & & \\
\hline $\operatorname{Trp}$ * & $0.437 \pm 0.060 \mathrm{a}$ & 1.86 & $0.322 \pm 0.065 \mathrm{a}$ & 1.38 & 0.7 & 1.5 \\
\hline
\end{tabular}

Lys-lysine; Met—methionine; Cys—cysteine; Asp—aspartic acid; Thr-threonine; Ser-serine; Glu—glutamic acid; Pro-proline; Gly_glycine; Ala_-alanine; Val—valine; Ile-isoleucine; Leu-leucine; Tyr-tyrosine; Phephenylalanine; His—histidine; Arg_arginine; Trp—tryptophan; * essential amino acids; ${ }^{* *}$ persons $>1$ year of age; a-mean values within a row are not significantly different $(p<0.05)$.

Protein quality is determined by the content of essential, exogenous amino acids. Based on this criterion, proteins from products of animal origin, such as eggs, milk, dairy products and meat (including poultry and fish), are treated as a complete protein. On the contrary, most plant proteins, due to their lower contents of essential amino acids-lysine, tryptophan, methionine and valine-are classified as incomplete. The amino acid composition of hemp protein draws our attention because of the perfect match of its Thr and Leu contents with those of the reference protein. According to IOM experts, the reference (theoretical) protein with a composition of essential amino acids that is optimal for humans contains $2.7 \mathrm{~g}$ Thr and $5.5 \mathrm{~g}$ Leu/100 $\mathrm{g}$ of protein (Table 4), which is precisely the amount calculated for the protein of the 'Henola' variety seeds. For the 'Bialobrzeskie' variety, the Thr content was slightly higher at $3.05 \mathrm{~g} / 100 \mathrm{~g}$. As shown in Table 5, the limiting amino acid in the hemp protein is Lys. In terms of the Tyr + Phe (average content for both varieties $6.21 \mathrm{~g} / 100 \mathrm{~g})$ and His (2.33 g/100 g) contents, hemp protein exhibited a great degree of similarity to egg protein, which is valued for its high biological value. 
Table 5. Amino Acid Score (AAS) (\%) for hemp protein according to protein pattern (IOM).

\begin{tabular}{ccc}
\hline Essential Amino Acid & 'Bialobrzeskie' & 'Henola' \\
\hline Ile & 141.20 & 136.80 \\
Leu & 101.09 & 100.36 \\
Lys & 62.75 & 63.14 \\
Met + Cys & 140.40 & 134.00 \\
Phe + Tyr & 132.13 & 132.13 \\
Thr & 112.76 & 102.59 \\
Trp & 265.71 & 197.14 \\
Val & 128.75 & 130.94 \\
His & 133.33 & 125.00 \\
\hline
\end{tabular}

Similar to many commercially available protein-rich plant products, such as broad beans, lupins, flax and rapeseed, hemp seeds are characterized by high contents of Glu, Arg and Asp. Due to the acid hydrolysis, glutamine and asparagine were completely converted into glutamic acid and aspartic acid. This also explains the high contents of amino acids that were found. The analyzed varieties of $C$. sativa contained, on average, $14.91,10.10$ and $8.91 \mathrm{~g}$ of these essential amino acids, respectively, per $100 \mathrm{~g}$ of protein. These values are similar to those obtained by Wang et al. [28]. Interestingly, these authors studied hemp protein isolates (HPI) and compared their amino acid compositions with FAO/WHO requirements for children aged 2-5 years. They found that, except for lysine and sulphur amino acids, the studied HPIs met the requirements for the age group mentioned above. Moreover, given its very high digestibility $(88-91 \%)$ and its amino acid profile, hemp protein isolates can successfully compete with soy isolates [28]. As a result, these preparations have application potential in the food industry, especially plant-based substitutes for meat and dairy products.

\section{Materials and Methods}

\subsection{Reagents and Analytical Standards}

FMOC (9-fluorenylmethyl chloroformate in acetonitrile) and OPA (ortho-phthaldialdehyde and 3-mercaptopropionic acid in borate buffer) from Agilent Technologies (Santa Clara, CA, USA) were used as derivatization reagents in the analysis of amino acids. An amino acid kit was purchased from Agilent Technologies (Waldbronn, Germany).

For fatty acids' determination, Supelco 37 Component FAME Mix (Supelco, Bellefonte, PA, USA) was used as a certified reference material (TraceCERT $\left.{ }^{\circledR}\right)$. Boron trifluoridemethanol solution ( $10 \%$, for GC derivatization), methanol and water (suitable for HPLC) were purchased from Sigma-Aldrich (Merck, Darmstadt, Germany). n-Hexane 99\% (suitable for Liquid Chromatography and UV-Spectrophotometry) was obtained from Macron Fine Chemicals ${ }^{\mathrm{TM}}$ (Avantor, Center Valley, PA, USA).

\subsection{Plant Material}

The test material consisted of unshelled seeds of industrial hemp (Cannabis sativa L. var. sativa) of the 'Henola' ('Zolotonowska 13' × 'Zenica') and 'Bialobrzeskie' (('LKCSD' $\times$ 'Kompolti') $\times$ 'Fibrimon') varieties purchased from the Institute of Natural Fibers and Medicinal Plant (INFMP, Poznań, Poland)/Polish Hemp Program in June 2020. After harvesting, the hemp seeds were dried with air $\left(30-35^{\circ} \mathrm{C}\right)$ to the humidity of approx. $8-11 \%$ and stored in a dry and airy room with humidity $<10 \%$.

The tested varieties were grown at the Institute of Natural Fibers and Medicinal Plants in Poznań. According to the specification given by INFMP, they are monoecious hemp with a high and stable degree of monoicy. They are central-European forms. Their growing season is adapted to Polish soil and climate conditions. For the 'Bialobrzeskie' variety, the growing period is $142-145$ days after sowing (DAS). The flowering period falls into the 70-75 DAS period. Ripe crops reach $250-350 \mathrm{~cm}$ in height, and their seed yield ranges from 0.8 to $1.0 \mathrm{t} / \mathrm{h}$. The growing period of the 'Henola' variety is estimated at 115-120 DAS 
and the flowering period at 48-55 DAS. The plant height is 170-200 cm and the seed yield is $1.5-2.1 \mathrm{t} /$ ha. In March 2021, both varieties were officially approved for cultivation also in the territory of Canada [41].

\subsection{Labelling Nutrition and Energy Value of Seeds}

Tests of the nutritional and energy value were carried out concerning the requirements of Regulation (EU) No 1169/2011 [42]. The hemp seeds were tested for energy value, protein content $(\mathrm{N} \times 6.25$; KjelFlex K-360, BÜCHI Labortechnik AG, Flawil, Switzerland), total fat (Soxhlet procedure; Automatic Soxhlet Extractor SOX606; Hannon Instruments, Jinan, China), digestible carbohydrates, total sugars, dry matter, salt and ash in accordance with AOAC methods (2007) [43]. The fiber content [44] was analyzed using the Bioquant 1.12979.0001 total dietary fiber enzymatic-gravimetric assay kit (Merck, Darmstadt, Germany).

\subsection{Determination of the Fatty Acid Profile Using GC-FID}

For fat extraction, hemp seed $( \pm 5.00 \mathrm{~g})$ was ground and then homogenized with a chloroform: methanol mixture $(2: 1 ; v / v)$ with $0.001 \%$ antioxidant (butylhydroxytolueneBHT). The solvent was evaporated in a nitrogen stream. The resulting crude lipid extract was saponified with $0.5 \mathrm{M} \mathrm{KOH}$ in methanol. The next stage included transesterification of fatty acids with the $\mathrm{BF}_{3}$ (boron trifluoride) solution in methanol as per the official AOCs Ce 2-66 method [45].

The conditions for chromatographic separation conformed with the procedure described by Wołoszyn et al. [46]. The methyl esters of fatty acids were quantified by GC-FID (Agilent 7890 A series, Agilent Tech. Inc.) using a J\&W Scientific HP-88 series $100 \mathrm{~m} \times 0.25 \mathrm{~mm} \times 0.20 \mu \mathrm{m}$ fused silica capillary column (Agilent Tech. Inc., St. Clara, CA, USA) and a flame-ionization detector (FID) from Agilent Tech.

\subsection{Calculation of Lipid Health Indicators}

Based on the analysis results for the fatty acid profile, selected nutritional quality parameters of the fat extracted from hemp seed were calculated. The following formulas were used for the calculations:

(1) PUFA $/$ SFA ratio $=(\Sigma$ DiUFA $+\Sigma$ TriUFA $+\Sigma$ TetraUFA $) / \Sigma$ SFA [35];

(2) $n-6 / n-3$ PUFA ratio $=(C 18: 2 n-6+\mathrm{C} 18: 3 n-6) /(\mathrm{C} 18: 3 n-3+\mathrm{C} 18: 4 n-3)$ [35];

(3) Atherogenicity Index AI $=(\mathrm{C} 12: 0+4 \times \mathrm{C} 14: 0+\mathrm{C} 16: 0) / \Sigma$ UFA [35];

(4) Thrombogenicity Index TI $=(\mathrm{C} 14: 0+\mathrm{C} 16: 0+\mathrm{C} 18: 0) /[(0.5 \times \mathrm{MUFA})+(0.5 \times \Sigma n-6)$ $\left.+\left(3 \times \sum n-3\right)+\left(\sum n-3 / \sum n-6\right)\right][38] ;$

(5) Hypocholesterolemic/Hypercholesterolemic Index $\mathrm{h} / \mathrm{H}=[(\mathrm{C} 18: 1 n-9+\mathrm{C} 18: 1 n-7$

$+\mathrm{C} 18: 2 n-6+\mathrm{C} 18: 3 n-6+\mathrm{C} 18: 3 n-3+\mathrm{C} 20: 3 n-6+\mathrm{C} 20: 4 n-6+\mathrm{C} 20: 5 n-3+$ $\mathrm{C} 22: 4 n-6+\mathrm{C} 22: 5 n-3+\mathrm{C} 22: 6 n-3) /(\mathrm{C} 14: 0+\mathrm{C} 16: 0)][47]$

\subsection{Determination of the Amino Acid Content with the HPLC-DAD}

The content of amino acids in hemp seeds was determined using high-performance liquid chromatography (HPLC) with the Agilent 1100 Series equipment coupled with the UV DAD detector and the reverse-phase AAA Eclipse Zorbax column (Agilent Technology Inc., St. Clara, CA, USA), $3.0 \times 150 \mathrm{~mm}, 3.5 \mu \mathrm{m}$ protected with an Agilent Technology column. The sample preparation was described in detail in the analytical procedure of Commission Regulation (EC) No 152/2009 [46].

The conditions for chromatographic separation of amino acids conformed with the ones proposed by Haraf et al. [48].

Cysteine was expressed as cysteic acid and methionine as methionine sulphone. 


\subsection{Calculation of AAS (Amino Acid Score)}

The AAS was calculated using the reference protein scoring pattern of persons $>1$ year of age (Institute of Medicine IOM, US) according to the following equation from Haraf et al. [48]:

AAS $=[(\mathrm{g}$ of amino acid in $100 \mathrm{~g}$ of a test protein $/ \mathrm{g}$ of amino acid in $100 \mathrm{~g}$ of requirement pattern)] $\times 100 \%$

The amino acid with the lowest percentage is called the limiting amino acid.

\subsection{Statistical Analysis}

Nutrition value and chromatographic data are presented as the mean $\pm \operatorname{SD}(n=3)$. Statistical analysis was performed using the Duncan test and one-way ANOVA. $p$-value $<0.05$ was considered to indicate a statistically significant difference.

\section{Conclusions}

Hemp is undoubtedly one of the crop plants with the most promising and versatile possible applications. Its seeds constitute a rich source of, among others, valuable protein and PUFA fatty acids with an excellent profile and exhibit great application potential not only in the production of oil but also a wide range of plant-based alternatives to animalorigin foods. As it follows from our research, hemp of the 'Bialobrzeskie' and 'Henola' varieties is a noteworthy raw material for food industry stakeholders who want to design modern, hypoallergenic plant food with outstanding nutritional value. Not only is its protein highly concentrated in seeds $(>23 \%)$, but it also has an interesting amino acid profile with many features in common with both the reference protein that is recognized by experts as well as egg protein. The fat content exceeding $30 \%$ with excellent values of the nutritional indices provides yet another unquestionable advantage of the studied varieties. However, the 'Henola' variety seems to be preferable for introduction and cultivation due to its shorter growing period and higher seed productivity These facts encourage further research on hemp seeds aimed at producing plant food and promoting this raw material.

Author Contributions: Conceptualization, M.T. and A.Z.; methodology, M.T. and A.Z.; software, M.T.; validation, M.T. and A.Z.; formal analysis, M.T.; investigation, M.T. and A.Z.; resources, T.R.; data curation, M.T.; writing-original draft preparation, M.T.; writing—review and editing, A.Z.; visualization, M.T.; supervision, T.R.; project administration, T.R.; funding acquisition, T.R. All authors have read and agreed to the published version of the manuscript.

Funding: This work was supported by the European Regional Development Fund under the Regional Operational Program of the Lower Silesia Province 2014-2020 (project No. RPDS.01.02.01-02-0038/20).

Institutional Review Board Statement: Not applicable.

Informed Consent Statement: Not applicable.

Data Availability Statement: All relevant data for the preparation of this manuscript are given in the text. Raw data used for preparation of this manuscript are available on request from the authors.

Acknowledgments: The authors are grateful to Gabriela Haraf for her technical assistance in HPLC support.

Conflicts of Interest: The authors declare no conflict of interest.

\section{References}

1. European Industrial Hemp Association Hemp Cultivation \& Production in Europe in 2018. Available online: https://eiha.org/ wp-content/uploads/2020/10/2018-Hemp-agri-report.pdf (accessed on 20 December 2021).

2. New Frontier Data Poland Embraces European Potential for Industrial Hemp. Available online: https: / newfrontierdata.com/ cannabis-insights / polands-rise-to-a-new-european-hemp-powerhouse/ (accessed on 11 August 2020).

3. COBORU (The Research Centre for Cultivar Testing). Oil and fibre plants. Pol. Nat. List Agric. Plant Var. 2021, $350,32-33$. 
4. Charitos, I.A.; Gagliano-Candela, R.; Santacroce, L.; Bottalico, L. The Cannabis Spread throughout the Continents and its Therapeutic Use in History. Endocr. Metab. Immune Disord. Drug Targets 2021, 21, 407-417. [CrossRef] [PubMed]

5. Bonini, S.A.; Premoli, M.; Tambaro, S.; Kumar, A.; Maccarinelli, G.; Memo, M.; Mastinu, A. Cannabis sativa: A comprehensive ethnopharmacological review of a medicinal plant with a long history. J. Ethnopharmacol. 2018, 227, 300-315. [CrossRef] [PubMed] 6. $\quad$ Abel, E.L. Marihuana; Springer US: Boston, MA, USA, 1980; ISBN 978-1-4899-2191-8.

7. Devinsky, O.; Marsh, E.; Friedman, D.; Thiele, E.; Laux, L.; Sullivan, J.; Miller, I.; Flamini, R.; Wilfong, A.; Filloux, F.; et al. Cannabidiol in patients with treatment-resistant epilepsy: An open-label interventional trial. Lancet Neurol. 2016, 15, 270-278. [CrossRef]

8. Koppel, B.S.; Brust, J.C.M.; Fife, T.; Bronstein, J.; Youssof, S.; Gronseth, G.; Gloss, D. Systematic review: Efficacy and safety of medical marijuana in selected neurologic disorders: Report of the Guideline Development Subcommittee of the American Academy of Neurology. Neurology 2014, 82, 1556-1563. [CrossRef]

9. Whiting, P.F.; Wolff, R.F.; Deshpande, S.; Di Nisio, M.; Duffy, S.; Hernandez, A.V.; Keurentjes, J.C.; Lang, S.; Misso, K.; Ryder, S.; et al. Cannabinoids for Medical Use. JAMA 2015, 313, 2456. [CrossRef]

10. Deshpande, A.; Mailis-Gagnon, A.; Zoheiry, N.; Lakha, S.F. Efficacy and adverse effects of medical marijuana for chronic noncancer pain: Systematic review of randomized controlled trials. Can. Fam. Physician 2015, 61, e372-e381.

11. Lynch, M.E.; Ware, M.A. Cannabinoids for the Treatment of Chronic Non-Cancer Pain: An Updated Systematic Review of Randomized Controlled Trials. J. Neuroimmune Pharmacol. 2015, 10, 293-301. [CrossRef]

12. Mücke, M.; Carter, C.; Cuhls, H.; Prüß, M.; Radbruch, L.; Häuser, W. Cannabinoide in der palliativen Versorgung. Der Schmerz 2016, 30, 25-36. [CrossRef]

13. Fitzcharles, M.-A.; Ste-Marie, P.A.; Häuser, W.; Clauw, D.J.; Jamal, S.; Karsh, J.; Landry, T.; Leclercq, S.; Mcdougall, J.J.; Shir, Y.; et al Efficacy, Tolerability, and Safety of Cannabinoid Treatments in the Rheumatic Diseases: A Systematic Review of Randomized Controlled Trials. Arthritis Care Res. 2016, 68, 681-688. [CrossRef]

14. Volz, M.S.; Siegmund, B.; Häuser, W. Wirksamkeit, Verträglichkeit und Sicherheit von Cannabinoiden in der Gastroenterologie. Der Schmerz 2016, 30, 37-46. [CrossRef] [PubMed]

15. European Commission. EU Agricultural Outlook for Markets, Income and Environment, 2020-2030; European Commission: Brussels, Belgium, 2020.

16. Aschemann-Witzel, J.; Gantriis, R.F.; Fraga, P.; Perez-Cueto, F.J.A. Plant-based food and protein trend from a business perspective: Markets, consumers, and the challenges and opportunities in the future. Crit. Rev. Food Sci. Nutr. 2020, 61, 1-10. [CrossRef] [PubMed]

17. Farinon, B.; Molinari, R.; Costantini, L.; Merendino, N. The Seed of Industrial Hemp (Cannabis sativa L.): Nutritional Quality and Potential Functionality for Human Health and Nutrition. Nutrients 2020, 12, 1935. [CrossRef] [PubMed]

18. Callaway, J.C. Hempseed as a nutritional resource: An overview. Euphytica 2004, 140, 65-72. [CrossRef]

19. Galasso, I.; Russo, R.; Mapelli, S.; Ponzoni, E.; Brambilla, I.M.; Battelli, G.; Reggiani, R. Variability in Seed Traits in a Collection of Cannabis sativa L. Genotypes. Front. Plant Sci. 2016, 7, 688. [CrossRef]

20. Irakli, M.; Tsaliki, E.; Kalivas, A.; Kleisiaris, F.; Sarrou, E.; Cook, C.M. Effect of Genotype and Growing Year on the Nutritional, Phytochemical, and Antioxidant Properties of Industrial Hemp (Cannabis sativa L.) Seeds. Antioxidants 2019, 8, 491. [CrossRef]

21. Vonapartis, E.; Aubin, M.-P.; Seguin, P.; Mustafa, A.F.; Charron, J.-B. Seed composition of ten industrial hemp cultivars approved for production in Canada. J. Food Compos. Anal. 2015, 39, 8-12. [CrossRef]

22. Lan, Y.; Zha, F.; Peckrul, A.; Hanson, B.; Johnson, B.; Rao, J.; Chen, B. Genotype x Environmental Effects on Yielding Ability and Seed Chemical Composition of Industrial Hemp (Cannabis sativa L.) Varieties Grown in North Dakota, USA. J. Am. Oil Chem. Soc. 2019, 96, 1417-1425. [CrossRef]

23. Mihoc, M.; Pop, G.; Alexa, E.; Radulov, I. Nutritive quality of romanian hemp varieties (Cannabis sativa L.) with special focus on oil and metal contents of seeds. Chem. Cent. J. 2012, 6, 122. [CrossRef]

24. Alonso-Esteban, J.I.; González-Fernández, M.J.; Fabrikov, D.; Torija-Isasa, E.; de Cortes Sánchez-Mata, M.; Guil-Guerrero, J.L. Hemp (Cannabis sativa L.) Varieties: Fatty Acid Profiles and Upgrading of $\gamma$-Linolenic Acid-Containing Hemp Seed Oils. Eur. J. Lipid Sci. Technol. 2020, 122, 1900445. [CrossRef]

25. Xu, Y.; Li, J.; Zhao, J.; Wang, W.; Griffin, J.; Li, Y.; Bean, S.; Tilley, M.; Wang, D. Hempseed as a nutritious and healthy human food or animal feed source: A review. Int. J. Food Sci. Technol. 2021, 56, 530-543. [CrossRef]

26. House, J.D.; Neufeld, J.; Leson, G. Evaluating the Quality of Protein from Hemp Seed (Cannabis sativa L.) Products Through the use of the Protein Digestibility-Corrected Amino Acid Score Method. J. Agric. Food Chem. 2010, 58, 11801-11807. [CrossRef] [PubMed]

27. Siano, F.; Moccia, S.; Picariello, G.; Russo, G.; Sorrentino, G.; Di Stasio, M.; La Cara, F.; Volpe, M. Comparative Study of Chemical, Biochemical Characteristic and ATR-FTIR Analysis of Seeds, Oil and Flour of the Edible Fedora Cultivar Hemp (Cannabis sativa L.). Molecules 2018, 24, 83. [CrossRef]

28. Wang, X.-S.; Tang, C.-H.; Yang, X.-Q.; Gao, W.-R. Characterization, amino acid composition and in vitro digestibility of hemp (Cannabis sativa L.) proteins. Food Chem. 2008, 107, 11-18. [CrossRef]

29. Razmaitè, V.; Pileckas, V.; Bliznikas, S.; Šiukščius, A. Fatty Acid Composition of Cannabis sativa, Linum usitatissimum and Camelina sativa Seeds Harvested in Lithuania for Food Use. Foods 2021, 10, 1902. [CrossRef]

30. Vahanvaty, U.S. Hemp Seed and Hemp Milk. ICAN Infant Child Adolesc. Nutr. 2009, 1, 232-234. [CrossRef] 
31. Mattila, P.; Mäkinen, S.; Eurola, M.; Jalava, T.; Pihlava, J.-M.; Hellström, J.; Pihlanto, A. Nutritional Value of Commercial Protein-Rich Plant Products. Plant Foods Hum. Nutr. 2018, 73, 108-115. [CrossRef]

32. Korus, J.; Witczak, M.; Ziobro, R.; Juszczak, L. Hemp (Cannabis sativa subsp. sativa) flour and protein preparation as natural nutrients and structure forming agents in starch based gluten-free bread. LWT 2017, 84, 143-150. [CrossRef]

33. Teterycz, D.; Sobota, A.; Przygodzka, D.; Łysakowska, P. Hemp seed (Cannabis sativa L.) enriched pasta: Physicochemical properties and quality evaluation. PLoS ONE 2021, 16, e248790. [CrossRef]

34. Surette, M.E. Dietary omega-3 PUFA and health: Stearidonic acid-containing seed oils as effective and sustainable alternatives to traditional marine oils. Mol. Nutr. Food Res. 2013, 57, 748-759. [CrossRef]

35. Chen, J.; Liu, H. Nutritional Indices for Assessing Fatty Acids: A Mini-Review. Int. J. Mol. Sci. 2020, 21, 5695. [CrossRef]

36. Tringaniello, C.; Cossignani, L.; Blasi, F. Characterization of the Triacylglycerol Fraction of Italian and Extra-European Hemp Seed Oil. Foods 2021, 10, 916. [CrossRef]

37. Kim, N.H.; Jung, S.Y.; Park, Y.A.; Lee, Y.J.; Jo, J.Y.; Lee, S.M.; Oh, Y.H. Fatty acid composition and characterisation of commercial vegetable oils with chemometric approaches. Int. Food Res. J. 2020, 27, 270-279.

38. Ulbricht, T.L.V.; Southgate, D.A.T. Coronary heart disease: Seven dietary factors. Lancet 1991, 338, 985-992. [CrossRef]

39. Ying, Q.; Wojciechowska, P.; Siger, A.; Kaczmarek, A.; Rudzińska, M. Phytochemical Content, Oxidative Stability, and Nutritional Properties of Unconventional Cold-pressed Edible Oils. J. Food Nutr. Res. 2018, 6, 476-485. [CrossRef]

40. Charzewska, J.; Jarosz, M.; Wajszczyk, B.; Chwojnowska, Z. Białka. In Normy Żywienia dla Populacji Polski i ich Zastosowanie; Jarosz, M., Rychlik, E., Stoś, K., Charzewska, J., Eds.; Narodowy Instytut Zdrowia Publicznego-Państwowy Zakład Higieny: Warsaw, Poland, 2020; pp. 48-68. ISBN 978-83-65870-28-5.

41. INFMP (Institute of Natural Fibres \& Medicinal Plants). Polish Industrial Hemp Varieties. Available online: https://www.iwnirz. $\mathrm{pl} /$ strona, 5,219.html (accessed on 14 April 2021).

42. European Parliament and of the Council. Regulation (EU) No 1169/2011 of the European Parliament and of the Council of 25 October 2011 on the Provision of Food Information to Consumers, Amending REGULATIONS (EC) No 1924/2006 and (EC) No 1925/2006 of the European Parliament and of the Council. Article 30. Off. J. Eur. Union 2011, 304, 34-35.

43. Latimer, G.W.; Horwitz, W. (Eds.) Official Methods of Analysis of AOAC International, 18th ed.; AOAC Intl.: Gaithersburg, MD, USA, 2007.

44. Cunnif, P. (Ed.) AOAC Official Method 985.29, Total Dietary in Foods-Enzymatic-Gravimetric Method. In Official Methods of Analysis of AOAC International, 16th ed.; Association of Official Analytical Chemists: Washington, DC, USA, 1995.

45. Firestone, D. (Ed.) AOCs Official Method Ce 2-66, Preparation of Methyl Esters of Fatty Acids. In Official Methods and Recommended Practices, 5th ed.; Oil Chemists' Society: Champaign, IL, USA, 1998.

46. Wołoszyn, J.; Haraf, G.; Okruszek, A.; Wereńska, M.; Goluch, Z.; Teleszko, M. Fatty acid profiles and health lipid indices in the breast muscles of local Polish goose varieties. Poult. Sci. 2020, 99, 1216-1224. [CrossRef] [PubMed]

47. Fernandes, C.E.; da Vasconcelos, M.A.S.; de Almeida Ribeiro, M.; Sarubbo, L.A.; Andrade, S.A.C.; de Filho, A.B.M. Nutritional and lipid profiles in marine fish species from Brazil. Food Chem. 2014, 160, 67-71. [CrossRef]

48. Haraf, G.; Wołoszyn, J.; Okruszek, A.; Orkusz, A.; Wereńska, M. Nutritional value of proteins and lipids in breast muscle of geese from four different Polish genotypes. Eur. Poult. Sci. 2018, 82, 1-11. 